\title{
Assessment of noise mitigation measures in urban areas
}

\author{
Tamara Džambas \\ University of Zagreb, Faculty of Civil Engineering, Dpt. of Transportation, Ph.D C.E. \\ tamara.dzambas@grad.unizg.hr \\ Vesna Dragčević \\ University of Zagreb, Faculty of Civil Engineering, Dpt. of Transportation, Ph.D C.E. \\ vesna.dragcevic@grad.unizg.hr \\ Mihaela Petrović \\ HIDROPROJEKT-ING projektiranje d.o.o., M.Eng.C.E., mihaelapetrovic14@gmail.com
}

\begin{abstract}
Within the scope of this study, the assessment of effectiveness of various traffic management and engineering noise mitigation measures at Masarykova Street located in the narrower centre of the city of Zagreb was made. Noise analyses were carried out by means of noise modelling procedure using the specialized noise prediction software LimA. Six different noise mitigation scenarios were observed, and optimal one regarding the amount of noise reduction in Masarykova Street and the amount of noise increase in adjacent streets was defined. Noise modelling results were validated by short term noise measurements carried out in day, evening, and night periods.
\end{abstract}

Key words: traffic noise, urban areas, noise mitigation measures, monitoring, measurements, modelling

\section{Ocjena učinkovitosti mjera za smanjenje razina buke u urbanim sredinama}

Sažetak: U radu je na primjeru Masarykove ulice smještene u užem centru grada Zagreba prikazan postupak ocjene učinkovitosti različitih mjera za smanjenje razina buke koje se odnose na upravljanje prometom. Analiza stanja bučnosti za šest različitih scenarija provedena je metodom računalnog modeliranja u specijaliziranom računalnom programu za predviđanje razina buke LimA, prilikom čega je definiran onaj optimalni koji je rezultirao najvećim smanjenjem razina buke u Masarykovoj ulici te najmanjim povećanjem razina buke u okolnim ulicama. Rezultati proračuna validirani su kratkotrajnim mjerenjima razina buke na terenu u dnevnom, večernjem i noćnom periodu.

Ključne riječi: prometna buka, urbane sredine, mjere za smanjenje razina buke, monitoring, mjerenja, modeliranje 


\section{INTRODUCTION}

Exposure to noise pollution is a bigger problem than ever before [1]. As urbanisation proceeds, with more than half of the global population and three quarters of the EU now living in urban areas, increasing numbers of people are being exposed to noise pollution [2]. The biggest source of environmental noise in urban areas is road traffic, exposure to which far exceeds rail and aircraft sources combined [3]. Common measures for mitigation of noise from road traffic in such highly populated areas are as follows: construction of low-noise road surfaces, development of quieter vehicle engines and low-noise tyres, and traffic management and engineering measures [4]. This last one refers to speed limits, free-traffic flow in night periods, redirection of a certain percentage of traffic to other roads in the city, banning the motor vehicles from entering the city centre, and encouraging drivers to drive more passively.

Speed limits do not only affect the traffic safety, but also the emission of road traffic noise [5]. Recent studies have shown that reducing the driving speed from $50 \mathrm{~km} / \mathrm{h}$ to 30 $\mathrm{km} / \mathrm{h}$ can lead to reduction of noise levels by up to $3 \mathrm{~dB}(\mathrm{~A})$ [6]. Turning off the traffic lights in night periods, on the other hand, can have a twofold effect: apart from ensuring a free traffic flow and eliminating undesirable stop and go operations, this noise mitigation measure can also lead to greater driving speeds. Consequently, it rarely results in a reduction of noise levels greater than $2 \mathrm{~dB}(\mathrm{~A})$ [7]. Furthermore, redirection of a certain percentage of traffic to other roads in the city is justified only when the traffic is diverted from a more congested road to side roads with low traffic volumes. Otherwise, this measure can even worsen the existing noise situation on the roads to which traffic was redirected. Less frequently used measures to mitigate traffic noise include banning private cars in city centre areas i.e. introducing a public transport (bus and taxi) area only, restricting private vehicles from accessing the narrower city centre during the peak hours, introducing "car free days", restricting the number of parking spaces in city centres, investing in cycling infrastructure and public transport. Several studies suggest that these measures can reduce noise levels by up to $10 \mathrm{~dB}(\mathrm{~A})[1]$.

Within the scope of this study, the assessment of effectiveness of previously described traffic management and engineering noise mitigation measures at Masarykova Street located in the narrower centre of the city of Zagreb was made.

\section{LOCATION DESCRIPTION}

Masarykova St. is a one-way urban street located in the vicinity of the central square of the city of Zagreb. Regarding the number of traffic lanes, this urban street can be divided in two main sections (Figure 1): $105 \mathrm{~m}$ long Section 1 with two traffic lanes positioned between the Republic of Croatia Square and Gundulićeva St. (on the former third lane on south side of the street there are café terraces), and $170 \mathrm{~m}$ long Section 2 with one traffic lane positioned between Gundulićeva St. and Preradovićeva St. (on the former second lane on north side of the street there is a taxi stand).

At Masarykova St. road traffic flows from west to east, and at the adjacent streets as follows: at Republic of Croatia Square from west to east and from north to south; at Gundulićeva St. from north to south and from south to north; at Preradovićeva St. from north to south; at Teslina St. from west to east - this street is used only by pedestrians, cyclists and taxi vehicles. The speed limit at Masarykova St. and adjacent streets is set to $50 \mathrm{~km} / \mathrm{h}$. At road intersections Republic of Croatia Square - Masarykova St. and Masarykova St. Gundulićeva St. traffic is regulated by traffic lights. At road intersection Masarykova St.- 
Džambas, T., Dragčević, V., Petrović, M.

Assessment of noise mitigation measures in urban areas

Preradovićeva St. - Teslina St. there are no traffic lights i.e. pedestrians have the right-ofway.

In the vicinity of the observed area there are mainly business, but also residential buildings, up to $18 \mathrm{~m}$ high. According to Croatian Rulebook on maximum permissible noise levels in areas where people work and live [8] and Master Plan of the city of Zagreb [9], noise levels in such areas should not exceed $65 \mathrm{~dB}(\mathrm{~A})$ in day and evening periods, and $50 \mathrm{~dB}(\mathrm{~A})$ in night period. Durations of these periods are prescribed by Croatian Law on noise protection [10] and they last as follows: day period from 7:00 a.m. to 7:00 p.m., evening period from 7:00 p.m. to 11:00 p.m., and night period from 11:00 p.m. to 7:00 a.m.

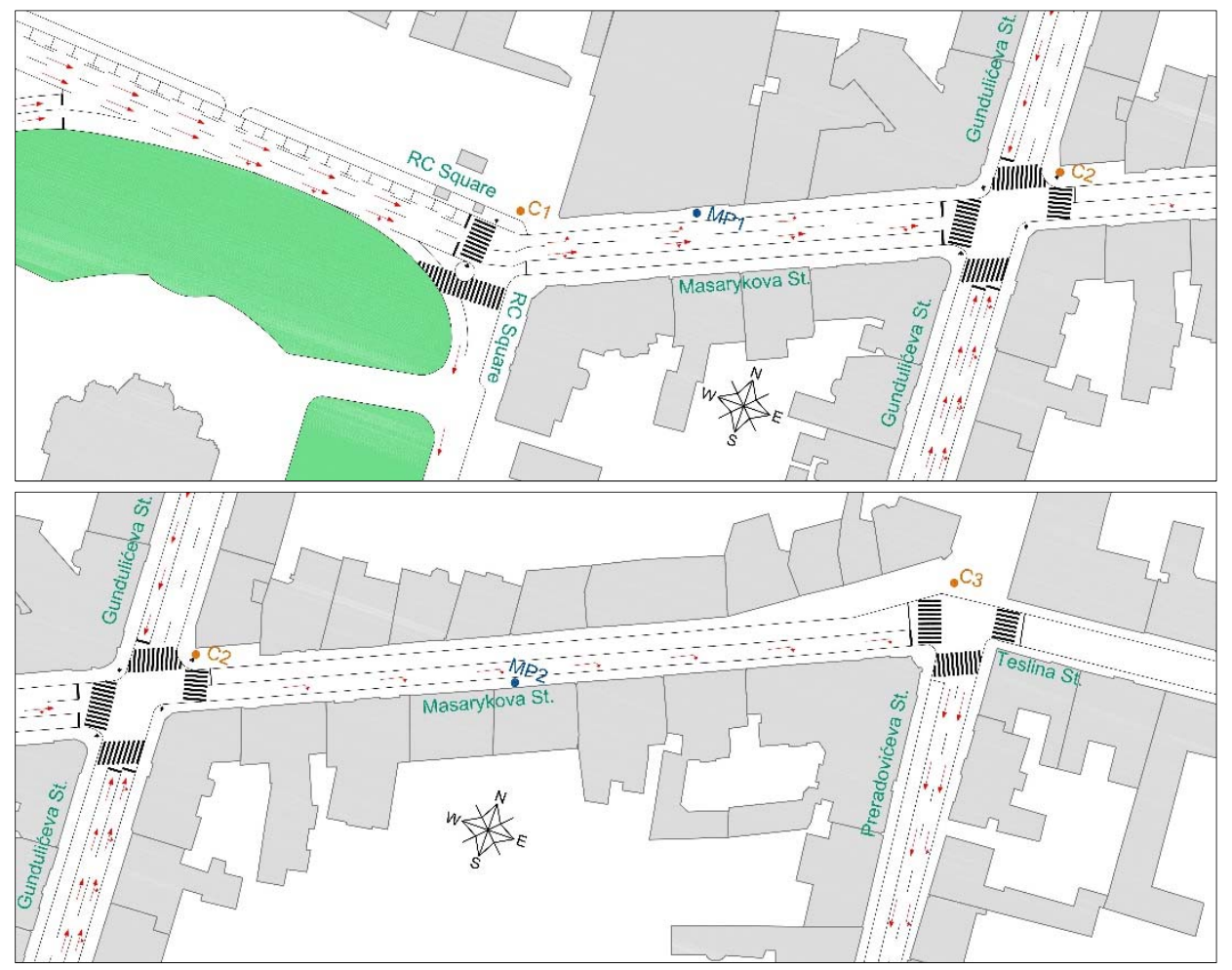

Figure 1. Masarykova Street in the city of Zagreb: Section 1 (up) and Section 2 (down)

\section{NOISE ANALYSES}

Noise analyses at Masarykova St. and adjacent streets included the traffic volume measurements, the noise modelling by means of specialised noise prediction software LimA, and the validation of applied noise calculation model by short-term noise measurements. In these analyses six noise mitigation scenarios were observed:

- $\mathrm{S} 1$ - current noise situation;

- S2 - banning the motor vehicles from entering the Section 2 of Masarykova St. (traffic from this section was redirected to the south side of Gundulićeva St.);

- S3 - banning the motor vehicles from entering the entire Masarykova St. (traffic from this section was redirected to the south i.e. to the Republic of Croatia Square where construction of second traffic lane was planned);

- S4 - ensuring a free-traffic flow in Masarykova St. in night period;

- S5 - redirection of a certain percentage of traffic $(10 \%, 30 \%, 50 \%)$ from Masarykova St. to adjacent streets; 
Džambas, T., Dragčević, V., Petrović, M.

Assessment of noise mitigation measures in urban areas

- S6 - introducing a "30 km/h" zone in Masarykova St. i.e. roadway sharing for motor vehicles and cyclists.

\subsection{Traffic volume measurements}

Short term traffic volume measurements were carried out by means of three video cameras (C1, C2, C3) placed at aforementioned road intersections in Masarykova St. (Figure 1, Figure 2). Measurements were conducted in day period from 8:00 a.m. to 9:00 a.m., evening period from 8:00 p.m. to 9:00 p.m., and night period from 11:00 p.m. to 12:00 p.m. Recorded vehicles were divided in two main groups: personal cars and delivery vehicles. As shown in Table 1, approx. $62 \%$ of the total traffic entering the Masarykova St. continues its course straight towards Preradovićeva St., while $36 \%$ of the traffic turns left and $2 \%$ right to Gundulićeva St.
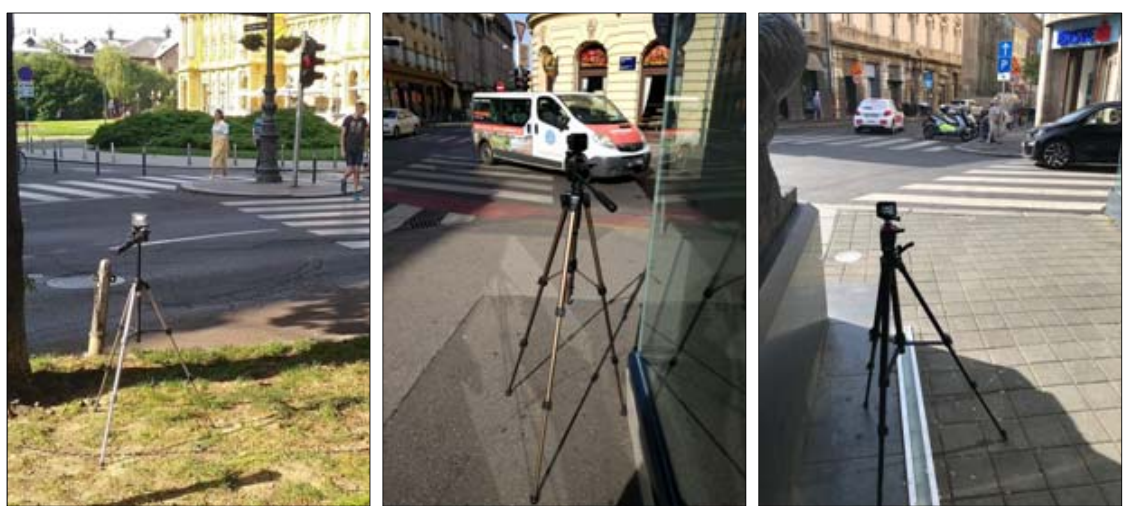

Figure 2. Traffic volume measurements at road intersections in Masarykova St.: C1 (left), C2 (middle), C3 (right)

Table 1. Results of traffic volume measurements

\begin{tabular}{|c|c|c|c|c|c|}
\hline \multirow{2}{*}{ Street } & \multirow{2}{*}{ Driving direction } & \multicolumn{2}{|c|}{ Day and evening period } & \multicolumn{2}{|c|}{ Night period } \\
\hline & & cars & delivery veh. & cars & delivery veh. \\
\hline \multirow{2}{*}{ RC Square } & straight & 966 & 26 & 208 & 2 \\
\hline & right & 657 & 22 & 173 & 1 \\
\hline \multirow{3}{*}{$\begin{array}{l}\text { Masarykova St. } \\
\text { (Section 1) }\end{array}$} & straight & 597 & 15 & 118 & 1 \\
\hline & right & 21 & 2 & 6 & 0 \\
\hline & left & 348 & 9 & 84 & 1 \\
\hline \multirow{2}{*}{$\begin{array}{l}\text { Masarykova St. } \\
\text { (Section 2) }\end{array}$} & straight & 6 & 0 & 4 & 0 \\
\hline & right & 698 & 23 & 177 & 1 \\
\hline \multirow{2}{*}{$\begin{array}{l}\text { Gundulićeva St. } \\
\text { (north) }\end{array}$} & straight & 11 & 0 & 21 & 0 \\
\hline & left & 4 & 1 & 7 & 0 \\
\hline \multirow{2}{*}{$\begin{array}{l}\text { Gundulićeva St. } \\
\text { (south) }\end{array}$} & straight & 452 & 18 & 188 & 0 \\
\hline & right & 103 & 7 & 56 & 0 \\
\hline
\end{tabular}

\subsection{Short-term noise measurements}

Noise measurements were carried out simultaneously with traffic volume measurements. They were conducted by means of two Brüel \& Kjaer sound level meters (type 2260 and type 2270) placed at the horizontal distance of $3.0 \mathrm{~m}$ from the axis of nearest traffic lane and at 
Džambas, T., Dragčević, V., Petrović, M.

Assessment of noise mitigation measures in urban areas

the height of $1.2 \mathrm{~m}$ above the ground (Figure 3). Measuring point MP1 was located in the central part of the Section 1 and measuring point MP2 in the central part of the Section 2 of Masarykova St. (Figure 1). Measurements were carried out under favourable meteorological conditions. Air temperature ranged from $18{ }^{\circ} \mathrm{C}$ to $21{ }^{\circ} \mathrm{C}$, wind speed from $2 \mathrm{~m} / \mathrm{s}$ to $3 \mathrm{~m} / \mathrm{s}$, humidity from $55 \%$ to $60 \%$, while the air pressure was around $1012 \mathrm{hPA}$. As shown in Table 2 , noise levels were higher than permitted at both measuring points in all periods.
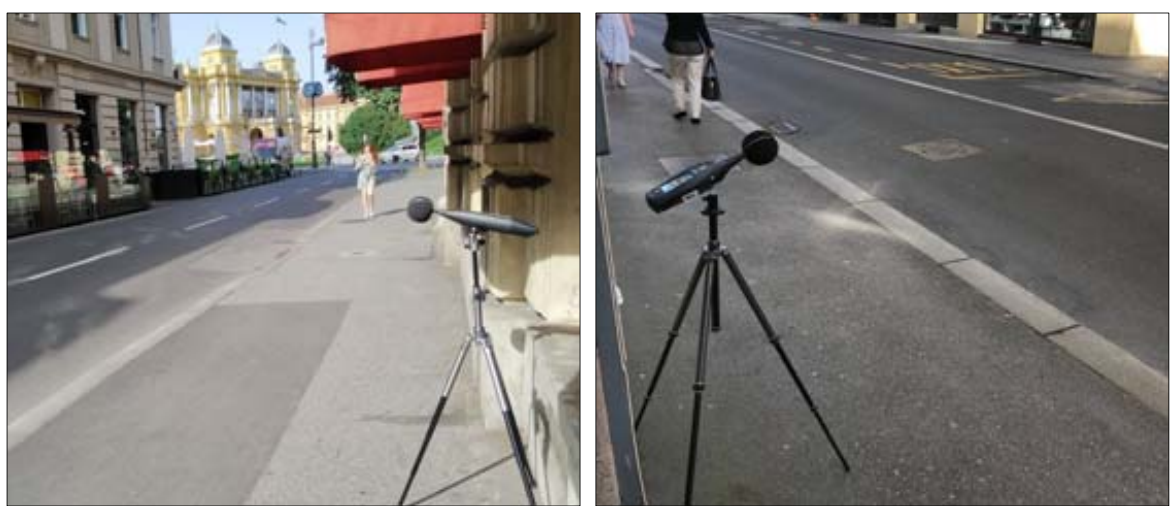

Figure 3. Noise measurements in Masarykova St.: MP1 (left), MP2 (right)

Table 2. Results of noise measurements

\begin{tabular}{|l|l|c|c|}
\hline \multirow{2}{*}{ Measuring point } & \multirow{2}{*}{$\begin{array}{l}\text { Measuring } \\
\text { device }\end{array}$} & day and evening period & night period \\
\cline { 3 - 4 } & B\&K 2260 & 67.4 & 59.1 \\
\hline MP1 & B\&K 2270 & 68.3 & 65.0 \\
\hline MP2 & & & L \\
\hline
\end{tabular}

\subsection{Noise modelling}

Noise modelling was carried using the interim NMPB-Routes-96 method for road traffic noise prediction recommended by Directive 2002/49/EC [11]. Noise source was placed at height of $0.5 \mathrm{~m}$ above all traffic lanes and the traffic data was obtained by previously described traffic volume measurements. The highest travelling speed of personal cars and delivery vehicles amounted to $30 \mathrm{~km} / \mathrm{h}$. Namely, despite the fact that the speed limit in the observed area was $50 \mathrm{~km} / \mathrm{h}$, the vehicles could not reach this speed due to relatively short segments between the road intersections and non-synchronized traffic lights.

In the vicinity of road intersections, a specific traffic flow condition for each traffic lane was defined. Lengths of the acceleration sections amounted to $60 \mathrm{~m}(2 \cdot \mathrm{Vmax})$ and lengths od deceleration sections $90 \mathrm{~m}$ (3.Vmax). The digital terrain model was approximated by a horizontal plane due to small longitudinal slopes and general flatness of the terrain, and the height of surrounding facilities was $3 \mathrm{~m}$ per floor.

Noise calculations were conducted at 34 free field receptors placed at the horizontal distance of $3.0 \mathrm{~m}$ from the axis of nearest traffic lane and at the height of $1.2 \mathrm{~m}$ above the ground (Figure 4):

- 2 free field receptors at measuring points MP1 and MP2 (FF_MP1, FF_MP2);

- 32 free field receptors in Masarykova and adjacent streets i.e. 4 receptors in each street (F_nn).

Comparison of noise measurement results at measuring points MP1 and MP2 (Table 2) and noise modelling results for current noise situation (S1) in free field receptors FF_MP1 and 
Džambas, T., Dragčević, V., Petrović, M.

Assessment of noise mitigation measures in urban areas

FF_MP2 (Table 3) has shown that the applied method for noise prediction is accurate enough largest difference between these results amounted to $2.7 \mathrm{~dB}(\mathrm{~A})$.

Average noise levels in free field receptors in Masarykova St. and adjacent streets for current noise situation (S1) are given in Table 4. They were calculated using the equation (1).

$$
\overline{L_{p}}=10 \cdot \log \cdot \frac{1}{n}\left(\sum_{i=1}^{n} 10^{L_{p} / 10}\right)
$$

where: $\overline{L_{p}}$ - average sound level pressure $(\mathrm{dB}(\mathrm{A})) ; n$ - number of free field receptors in each street (-); $L_{p}$ - sound level pressure in free field receptor $(\mathrm{dB}(\mathrm{A}))$.

As it can be seen from Table 4, these average noise levels were higher than permitted in all analysed streets and periods, except in Teslina St. in day and evening periods. Consequently, a comparison between the average noise levels for current noise situation (S1) and the average noise levels for other noise mitigation scenarios (S2, S3, S4, S5, S6) was made (Figure 5).

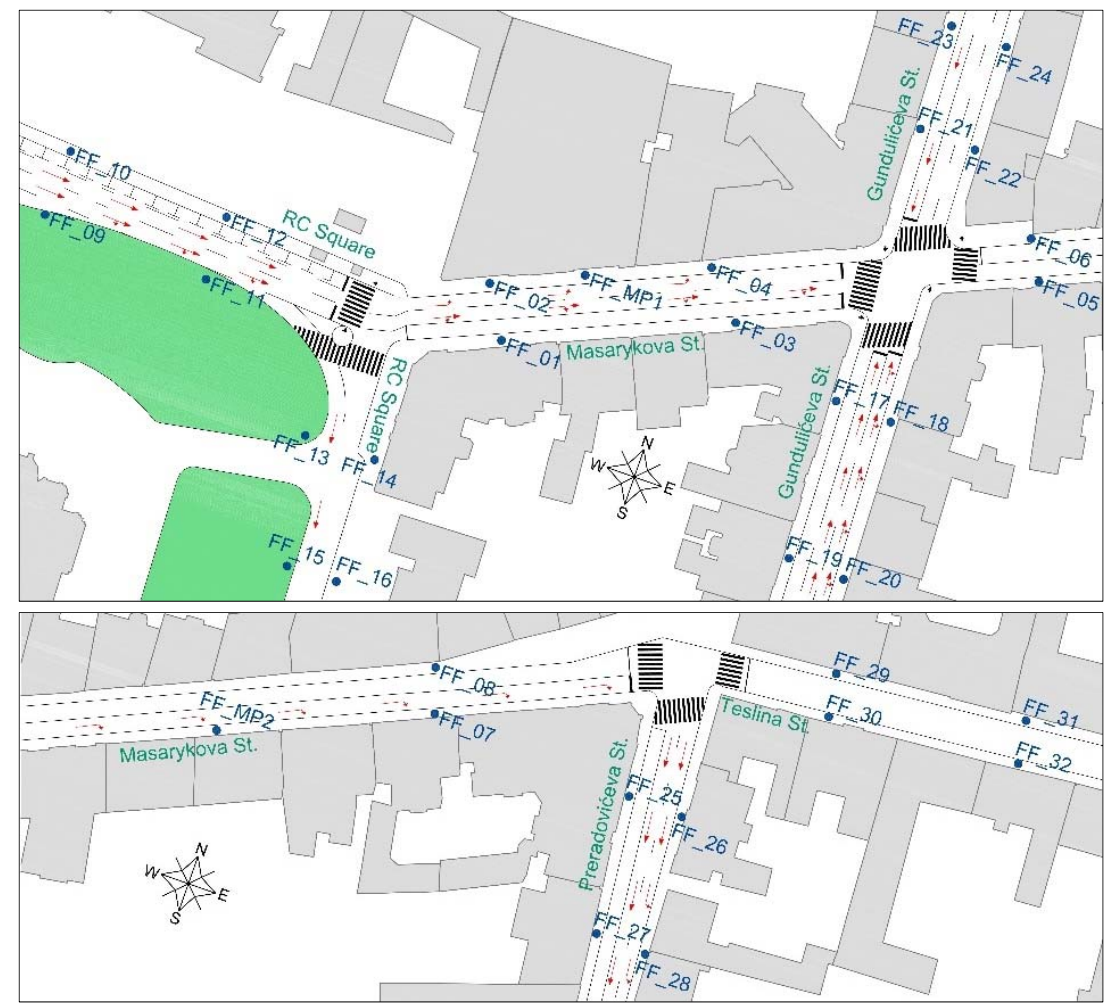

Figure 4. Locations of free field receptors

Table 3. Noise modelling results

\begin{tabular}{|l|c|c|}
\hline \multirow{2}{*}{ Free field receptor } & \multicolumn{2}{|c|}{$\mathrm{L}_{\mathrm{A}, \mathrm{eq}}[\mathrm{dB}(\mathrm{A})]$} \\
\cline { 2 - 3 } & day and evening period & night period \\
\hline FF_MP1 & 69.6 & 61.8 \\
\hline FF_MP2 & 70.4 & 64.0 \\
\hline
\end{tabular}


Džambas, T., Dragčević, V., Petrović, M.

Assessment of noise mitigation measures in urban areas

Table 4. Noise modelling results for current noise situation (S1)

\begin{tabular}{|c|c|c|c|c|c|c|c|c|}
\hline \multirow[b]{2}{*}{ Period } & \multicolumn{8}{|c|}{$L_{A, e q}[d B(A)]$} \\
\hline & 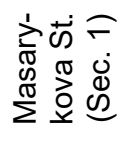 & 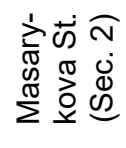 & 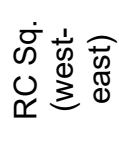 & 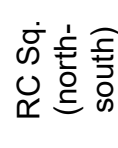 & 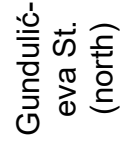 & 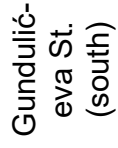 & 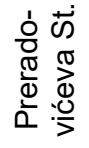 & 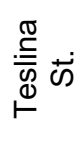 \\
\hline Day and evening & 71.0 & 70.4 & 69.6 & 67.4 & 68.6 & 67.3 & 71.5 & 61.6 \\
\hline Night & 64.2 & 63.8 & 62.9 & 61.0 & 63.3 & 62.8 & 62.9 & 54.8 \\
\hline
\end{tabular}

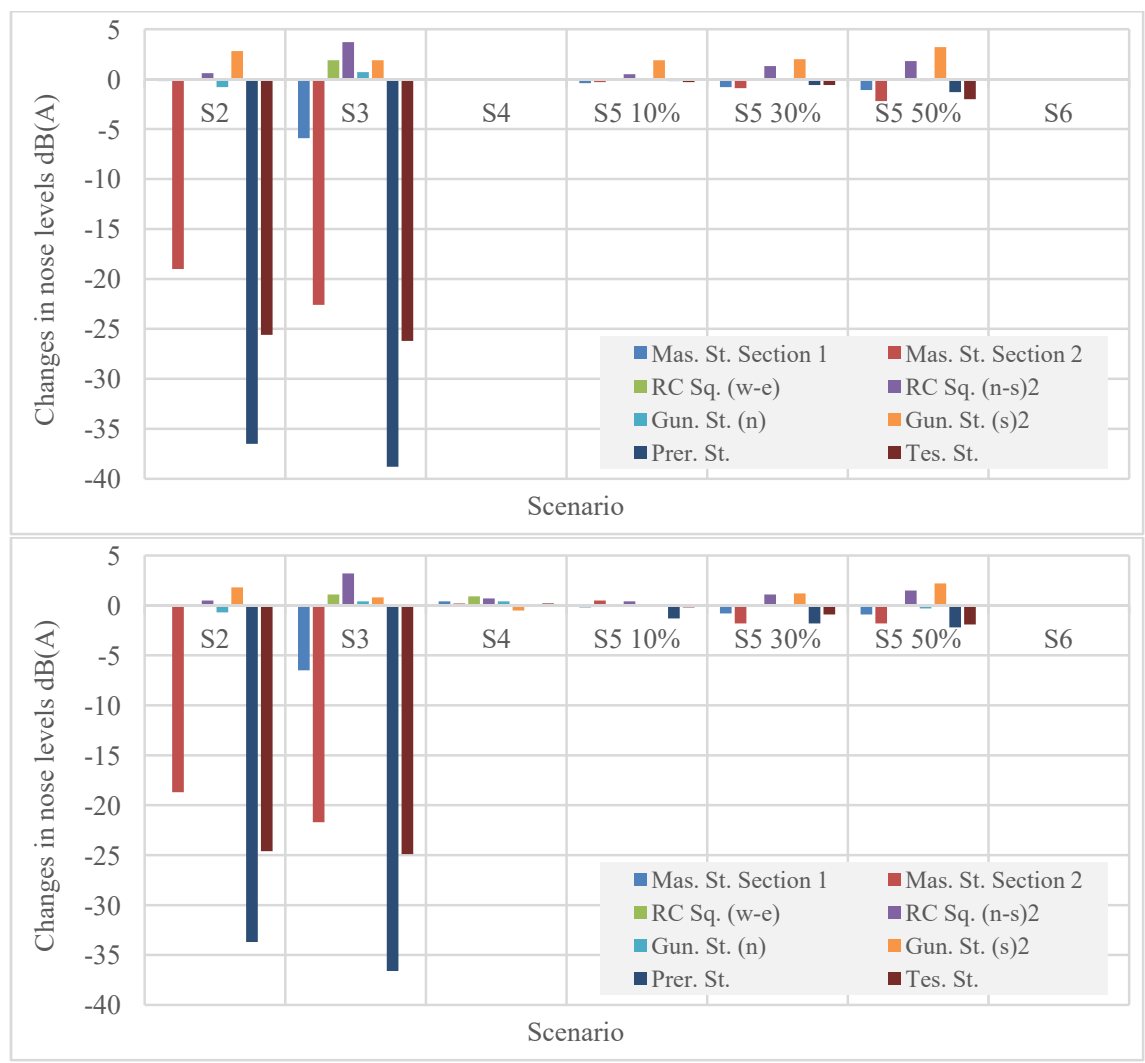

Figure 5. Changes in noise levels for different noise mitigation scenarios: in day and evening periods (up), in night period (down)

\section{DISCUSSIONS AND CONCLUSIONS}

Results of noise analyses carried out within the scope of this study have shown the following. Existing noise levels in Masarykova St. and adjacent streets are generally higher than maximum permissible noise levels prescribed by Croatian Rulebook and Master Plan of the city of Zagreb. In day and evening periods these maximum permissible noise levels are exceeded by up to 6.5 $\mathrm{dB}(\mathrm{A})$ and in night period by up to $14.2 \mathrm{~dB}(\mathrm{~A})$. These rather high noise levels in the night period significantly impair the human health because they cause sleep disorders and consequently inhibit the normal functioning of the human body during the day period. In view of the foregoing, assessment of effectiveness of several traffic management and engineering noise mitigation measures commonly used in such highly populated urban areas was made (Figure 5). 
As expected, noise mitigation measures from scenarios S2 (banning the motor vehicles from entering the Section 2 of Masarykova St.) and S3 (banning the motor vehicles from entering the entire Masarykova St.) have proven to be the most effective. In the case of Scenario 2, noise levels in Section 2 of Masarykova St. were significantly reduced (up to 19 $\mathrm{dB}(\mathrm{A})$ in day and evening periods, up to $18.7 \mathrm{~dB}(\mathrm{~A})$ in night period), whereby they become lower than maximum permissible noise levels prescribed by existing regulations. In the case of Scenario 3, noise levels in Section 2 of Masarykova St. were also notably reduced (up to 22.,6 $\mathrm{dB}(\mathrm{A})$ in day and evening periods, up to $21.7 \mathrm{~dB}(\mathrm{~A})$ in night period), but the noise situation in Section 1 of Masarykova St. has not changed radically. Namely, in this section of Masarykova St. noise levels in night period were still higher than permitted due to the greater traffic volumes at Republic of Croatia Square. Nonetheless, noise mitigation measures from scenarios S2 and S3 led to significant reduction of noise levels in adjacent Preradovićeva St. and Teslina St. (up to $38.8 \mathrm{~dB}(\mathrm{~A})$ in day and evening periods, up to $36.6 \mathrm{~dB}(\mathrm{~A})$ in night period), and a rather low increase of noise levels in Gundulićeva St. and Republic of Croatia Square (up to $3.7 \mathrm{~dB}(A)$ in day and evening periods, up to $3.2 \mathrm{~dB}(\mathrm{~A})$ in night period). In the light of above considerations, it can be concluded that the noise mitigation measure from Scenario $\mathrm{S} 2$ was more favourable regarding the amount of noise reduction in Masarykova Street than the measure from Scenario 3 , and that banning the motor vehicles from entering the urban street with high noise levels can be a quite efficient mitigation measure when noise levels in adjacent streets are even slightly lower than permitted.

Noise mitigation measures from scenarios S4 (ensuring a free-traffic flow in Masarykova St. in night period) and S5 (redirection of a certain percentage of traffic from Masarykova St. to adjacent streets) have not resulted in notable decrease of noise levels in Masarykova St. (new noise levels in Masarykova St. were still higher than permitted) or notable increase of noise levels in adjacent streets. As a matter of fact, when the traffic lights were turned off in night period noise levels in Masarykova St. were slightly increased (up to $0.4 \mathrm{~dB}(\mathrm{~A})$ ). Consequently, it can be concluded that this noise mitigation measure could lead to greater driving speeds which can even worsen the existing noise situation.

Noise mitigation measure from scenario 6 (introducing a "30 km/h" zone in Masarykova St.) could not be assessed due to the fact that highest travelling speed of personal cars and delivery vehicles in Masarykova St. was $30 \mathrm{~km} / \mathrm{h}$.

Finally, a conversion of Section 2 of Masarykova St. into a pedestrian zone (Scenario 2) has proven to be the most effective noise mitigation measure in this research, while a free traffic flow in night period (Scenario 4) even worsened the existing noise situation in this street. Furthermore, noise mitigation measures from scenarios 4,5 and 6 could not be assessed properly due to large traffic volumes in Masarykova St. and adjacent streets, and a rather short segments between road intersections. Namely, these noise mitigation measures would probably be more efficient if their impact on reduction of noise levels was analysed within a larger area (e.g. within the entire urban zone), and not only in the immediate vicinity of one urban street. In the light of above considerations, a larger urban area consisting of streets with longer sections between road intersections should be chosen for analyses in future research. Thereby, a modelling of traffic flow and an assessment of effectiveness of different noise mitigation measures would be much easier and probably more accurate.

\section{REFERENCES}

1. Future brief: Noise abatement approaches, Issue 17, European Commission, 2017.

2. Urban environment: European Environment Agency, http://www.eea.europa.eu, 03.01.2020.

3. Murphy, E., King, E.: Environmental Noise Pollution, 1st Edition, Elsevier, 2014. 
Džambas, T., Dragčević, V., Petrović, M.

Assessment of noise mitigation measures in urban areas

4. Lakušić, S., Dragčević, V., Rukavina, T.: Mitigation measures for traffic noise abatement in urban areas, GRAĐEVINAR, 57 (2005) 1, pp. 1-9.

5. Healthier Environment through Abatement of Vehicle Emission and Noise: Transport Research \& Innovation Portal, http://www.transport-research.info/project/healthierenvironment-through-abatement-vehicleemission-and-noise, 12.12.2019.

6. Nieuwenhuijsen, M.J., Khreis, H.: Car free cities - Pathway to healthy urban living, Environment International 94 (2016), pp. 251-262.

7. Inventory of noise mitigation methods: The European Commission Working Group 5: Abatement, https://www.hoevelakenbereikbaar.nl, 11.02.2020.

8. Rulebook on maximum permissible noise levels in areas where people work and live, OG $145 / 04$.

9. City of Zagreb: Master Plan of the city of Zagreb, https://www.zagreb.hr, 28.04.2020.

10. Law on noise protection, OG 30/2009.

11. Directive 2002/49/EC of the European Parliament and of the Council of 25 June 2002 relating to the assessment and management of environmental noise. $14 \mathrm{p}$. 